\title{
Digital Health Solutions to Control the COVID-19 Pandemic in Countries With High Disease Prevalence: Literature Review
}

Sharareh R Niakan Kalhori ${ }^{1}$, PhD; Kambiz Bahaadinbeigy ${ }^{2}$, PhD; Kolsoum Deldar ${ }^{3}$, PhD; Marsa Gholamzadeh ${ }^{1}$, MSc; Sadrieh Hajesmaeel-Gohari ${ }^{4}, \mathrm{PhD}$; Seyed Mohammad Ayyoubzadeh ${ }^{1}, \mathrm{PhD}$

\footnotetext{
${ }^{1}$ Department of Health Information Management, Tehran University of Medical Sciences, Tehran, Iran

${ }^{2}$ Modeling in Health Research Center, Institute for Future Studies in Health, Kerman University of Medical Sciences, Kerman, Iran

${ }^{3}$ School of Paramedicine, Shahroud University of Medical Sciences, Shahroud, Iran

${ }^{4}$ Medical Informatics Research Center, Institute for Futures Studies in Health, Kerman University of Medical Sciences, Kerman, Iran
}

\section{Corresponding Author:}

Seyed Mohammad Ayyoubzadeh, $\mathrm{PhD}$

Department of Health Information Management

Tehran University of Medical Sciences

3rd Floor, School of Allied Medical Sciences

No \#17, Farredanesh Alley, Ghods St, Enghelab Ave

Tehran

Iran

Phone: 982188983025

Email: s.m.ayyoubzadeh@gmail.com

\section{Abstract}

Background: COVID-19, the disease caused by the novel coronavirus SARS-CoV-2, has become a global pandemic, affecting most countries worldwide. Digital health information technologies can be applied in three aspects, namely digital patients, digital devices, and digital clinics, and could be useful in fighting the COVID-19 pandemic.

Objective: Recent reviews have examined the role of digital health in controlling COVID-19 to identify the potential of digital health interventions to fight the disease. However, this study aims to review and analyze the digital technology that is being applied to control the COVID-19 pandemic in the 10 countries with the highest prevalence of the disease.

Methods: For this review, the Google Scholar, PubMed, Web of Science, and Scopus databases were searched in August 2020 to retrieve publications from December 2019 to March 15, 2020. Furthermore, the Google search engine was used to identify additional applications of digital health for COVID-19 pandemic control.

Results: We included 32 papers in this review that reported 37 digital health applications for COVID-19 control. The most common digital health projects to address COVID-19 were telemedicine visits $(11 / 37,30 \%)$. Digital learning packages for informing people about the disease, geographic information systems and quick response code applications for real-time case tracking, and cloud- or mobile-based systems for self-care and patient tracking were in the second rank of digital tool applications (all 7/37, 19\%). The projects were deployed in various European countries and in the United States, Australia, and China.

Conclusions: Considering the potential of available information technologies worldwide in the 21 st century, particularly in developed countries, it appears that more digital health products with a higher level of intelligence capability remain to be applied for the management of pandemics and health-related crises.

(J Med Internet Res 2021;23(3):e19473) doi: 10.2196/19473

\section{KEYWORDS}

COVID-19; digital health; information technology; telemedicine; electronic health

\section{Introduction}

The novel disease COVID-19, caused by the novel coronavirus SARS-CoV-2, was originally recognized in December 2019 as a case of pneumonia in Wuhan, China; it has since become a global pandemic, affecting most countries worldwide [1]. On March 11, the World Health Organization announced the outbreak of a pandemic and asked for coordinated mechanisms to support readiness and rapid response to the infection across 
the world's health sectors [2]. As the incidence of COVID-19 continues to rise, health care systems are rapidly facing growing clinical demands [3]. Operational management of a pandemic in the era of modern medicine requires novel technologies, such as digital health, that can support the management of COVID-19 cases in different stages [4]. Digital health as an application of information technology has already been used to improve health care organizations; for example, the National Health Service (NHS) in the United Kingdom has established the NHS Digital information center [5]. Digital health is defined as information technologies that can be applied in three aspects: digital patients, digital devices, and digital clinics. A digital patient is a patient who uses and engages with mobile health (mHealth) devices to change and sustain their behavior, including technologies such as telemedicine, patient self-measurements, and digital retention. Digital devices help solve clinical problems and include smartphone-connected rhythm monitoring devices, wireless and wearable devices, and implantable and ingestible sensors. The digital clinic aspect focuses on generating mHealth data, analyzing it so that it is clinically meaningful, and integrating it within clinical workflows. Aspects of digital clinics include precision-based mHealth and n-of-1 designs, population-based mHealth interventions in resource-limited areas, and mHealth regulation and integration [6].

During the COVID-19 pandemic, digital health-based tools may support organizations and societies more efficiently. They are useful for instant, widespread distribution of information, real-time transmission tracking, virtual venue creation for meetings and official day-to-day operations, and telemedicine visits for patients [7-12]. Such applications during the COVID-19 pandemic have been reported in several publications [13-15]. During the recent months of the COVID-19 outbreak, as countries and their responsible organizations such as health ministries and other officials have focused on controlling the pandemic, many supportive and reliable informatics infrastructures have been developed [12]. These infrastructures were applied in practice to prepare to manage an exponential increase in patients with COVID-19. Various digital health strategies have been used for disease control in different countries. A study conducted by Calton et al [16] provided some tips for applying telemedicine as a means to reduce the transmission of COVID-19. A study conducted by Moazzami et al [17] focused on employing telemedicine to prevent disease among health care providers. A study conducted by Keesara et al [18] referred to the capabilities and potential of digital health to fight COVID-19. However, they reviewed digital health-related solutions in general to address how this technology can support health care systems through introducing various strategic roles, such as surveillance, screening, triage, diagnosis, and monitoring, and contact tracing; no data regarding the use of this approach in practice for fighting COVID-19 were provided [19]. Fagherazzi et al [20] emphasized that the great potential of digital technology for COVID-19 control should be considered at the top level of health systems; they also discussed the challenges that policy makers may face in controlling the crisis using digital solutions. Furthermore, in a macro vision, they revealed the required societal and environmental restructuring required for successfully applying digital health technology to control COVID-19, including the health care system, government, public, industry, environment, and energy [15]. These reviews depict a general image regarding the requirement of digital system use and their applications worldwide [21], with no focus on any specific application in a specific country or region. Although these studies have shed light on the topic of applying digital health solutions for COVID-19 control, there is a gap of deep understanding regarding the application of these technologies in countries where COVID-19 is highly prevalent.

Therefore, this study aimed to review and analyze applied information technology and digital health-related strategies to control the COVID-19 pandemic in the 10 countries with the highest prevalence of the disease.

\section{Methods}

In this review study, the databases of Google Scholar, PubMed, Web of Science, and Scopus were searched in August 2020 to retrieve publications from December 2019 to August 15, 2020. The combination of keywords for searching is shown below:

("Corona virus" OR "COVID I9" OR
"coronavirus") AND(computer OR internet OR web*
OR mobile OR smart OR email OR video confer* OR
telecommunication OR ICT OR "information
technology" OR ehealth OR telehealth OR mHealth
OR telecare OR telehealth OR telemedicine OR
telemonitoring OR digital OR wearable OR IoT OR
cloud) AND (Italy OR Spain OR USA OR France OR
UK OR Iran OR China OR Netherlands OR Germany
OR Belgium)

The inclusion criteria were publications that introduce digital health applications to manage and control COVID-19 in humans, and the exclusion criteria were non-English publications, publications with no abstract, research on data analysis and modeling for prediction of epidemiological parameters, letters to the editor, and review studies. Data were analyzed using descriptive methods. Qualitative analysis of the included studies was performed based on predefined categories. A summary of the reviewed articles is provided in Table 1 . Several items were analyzed in each paper, including (1) publication month; (2) country (Italy, Spain, United States, France, United Kingdom, Iran, China, the Netherlands, Germany, and Belgium, as they were the countries where COVID-19 was most prevalent according to the Worldometer website [22]); (3) purpose of the study, including screening, prevention, diagnosis, treatment, and follow-up of cases (defined as follows: screening: no symptom + no contact with COVID-19 patients; prevention: no symptom + contact with COVID-19 patients with no symptoms; diagnosis: having disease symptoms; treatment of COVID-19 cases: decreasing symptoms dramatically; and follow-up: discharged cases with the fewest symptoms); (4) scope and territory (village, city, region/province, state, country, and international), (5) digital tools, including robots, the Internet of Things, videoconferencing, web-based systems, cloud-based systems, wearable devices, clinical decision support systems (CDSSs), intelligent systems, smartphones, mobile apps, telecommunication systems, websites, digital media, and digital quick response $(\mathrm{QR})$ codes. 
Table 1. Details of the reviewed papers that discussed the application of digital health tools to control the COVID-19 pandemic.

\begin{tabular}{|c|c|c|c|c|c|c|c|}
\hline Author & Journal & $\begin{array}{l}\text { Publication } \\
\text { month } \\
(2020)\end{array}$ & Country & Purpose & $\begin{array}{l}\text { Scope and } \\
\text { territory }\end{array}$ & $\begin{array}{l}\text { Applied digital } \\
\text { tools }\end{array}$ & $\begin{array}{l}\text { Application of digital } \\
\text { tools }\end{array}$ \\
\hline $\begin{array}{l}\text { Kamel and Ger- } \\
\text { aghty [23] }\end{array}$ & $\begin{array}{l}\text { International Journal of } \\
\text { Health Geographics }\end{array}$ & March & China & Prevention & $\begin{array}{l}\text { Internation- } \\
\text { al }\end{array}$ & $\begin{array}{l}\text { Web-based sys- } \\
\text { tems, mobile } \\
\text { apps, GIS }\end{array}$ & $\begin{array}{l}\text { Widespread distribu- } \\
\text { tion of information } \\
\text { and real-time tracking } \\
\text { of transmission }\end{array}$ \\
\hline Yang et al [24] & Clinical Oral Investigations & May & China & $\begin{array}{l}\text { Treatment } \\
\text { and follow- } \\
\text { up }\end{array}$ & Country & $\begin{array}{l}\text { Web-based sys- } \\
\text { tems, mobile } \\
\text { apps }\end{array}$ & $\begin{array}{l}\text { Telemedicine visits } \\
\text { for patients }\end{array}$ \\
\hline Meng et al [25] & $\begin{array}{l}\text { International Journal of } \\
\text { Clinical Pharmacy }\end{array}$ & April & China & Treatment & Region & $\begin{array}{l}\text { Cloud-based sys- } \\
\text { tems, smart- } \\
\text { phones, telecom- } \\
\text { munication sys- } \\
\text { tems }\end{array}$ & $\begin{array}{l}\text { Provision of pharma- } \\
\text { ceutical care activities } \\
\text { to patients and physi- } \\
\text { cians by pharmacists }\end{array}$ \\
\hline $\begin{array}{l}\text { Ohannessian et al } \\
\text { [26] }\end{array}$ & $\begin{array}{l}\text { JMIR Public Health and } \\
\text { Surveillance }\end{array}$ & February & France & Prevention & Country & $\begin{array}{l}\text { Videoconferenc- } \\
\text { ing }\end{array}$ & $\begin{array}{l}\text { Offering telemedicine } \\
\text { visits for patients }\end{array}$ \\
\hline Pan et al [27] & Microbes and Infection & February & China & Prevention & Country & Mobile apps & $\begin{array}{l}\text { Widespread distribu- } \\
\text { tion of information } \\
\text { and real-time tracking } \\
\text { of transmission }\end{array}$ \\
\hline Pan et al [28] & $\begin{array}{l}\text { Irish Journal of Medical } \\
\text { Science }\end{array}$ & March & China & $\begin{array}{l}\text { Screening } \\
\text { and preven- } \\
\text { tion }\end{array}$ & $\begin{array}{l}\text { City and } \\
\text { country }\end{array}$ & Mobile apps & $\begin{array}{l}\text { Real-time tracking of } \\
\text { transmission }\end{array}$ \\
\hline Sun et al [29] & Annals of Intensive Care & March & China & Treatment & State & $\begin{array}{l}\text { Intelligent sys- } \\
\text { tems }\end{array}$ & $\begin{array}{l}\text { Early warning sys- } \\
\text { tems and screening } \\
\text { procedures for pa- } \\
\text { tients }\end{array}$ \\
\hline $\begin{array}{l}\text { Hernández-Gar- } \\
\text { cia and Gimenez- } \\
\text { Júlvez [30] }\end{array}$ & $\begin{array}{l}\text { JMIR Public Health and } \\
\text { Surveillance }\end{array}$ & April & $\begin{array}{l}\text { Collabora- } \\
\text { tion of the } \\
\text { United } \\
\text { States, } \\
\text { Spain, } \\
\text { Switzerland, } \\
\text { the United } \\
\text { Kingdom, } \\
\text { Sweden, and } \\
\text { Canada }\end{array}$ & $\begin{array}{l}\text { Screening } \\
\text { and preven- } \\
\text { tion }\end{array}$ & $\begin{array}{l}\text { Internation- } \\
\text { al }\end{array}$ & $\begin{array}{l}\text { Websites and } \\
\text { digital media }\end{array}$ & $\begin{array}{l}\text { Widespread distribu- } \\
\text { tion of information }\end{array}$ \\
\hline $\begin{array}{l}\text { Hua and Shaw } \\
\text { [31] }\end{array}$ & $\begin{array}{l}\text { International Journal of En- } \\
\text { vironmental Research and } \\
\text { Public Health }\end{array}$ & March & China & $\begin{array}{l}\text { Screening, } \\
\text { prevention, } \\
\text { and follow- } \\
\text { up }\end{array}$ & $\begin{array}{l}\text { Region/ } \\
\text { province }\end{array}$ & $\begin{array}{l}\text { Web-based sys- } \\
\text { tems, smart- } \\
\text { phones, websites, } \\
\text { digital media, } \\
\text { digital } \mathrm{QR}^{\mathrm{b}} \text { codes }\end{array}$ & $\begin{array}{l}\text { Widespread distribu- } \\
\text { tion of information, } \\
\text { real-time tracking of } \\
\text { transmission, provi- } \\
\text { sion of information } \\
\text { about "fake news" and } \\
\text { rumors }\end{array}$ \\
\hline Drew et al [32] & Science & May & $\begin{array}{l}\text { United King- } \\
\text { dom, United } \\
\text { States }\end{array}$ & Screening & $\begin{array}{l}\text { Internation- } \\
\text { al }\end{array}$ & Mobile app & $\begin{array}{l}\text { Widespread distribu- } \\
\text { tion of information, } \\
\text { real-time tracking of } \\
\text { transmission }\end{array}$ \\
\hline Franco et al [33] & Global Spine Journal & June & $\begin{array}{l}\text { United } \\
\text { States }\end{array}$ & Treatment & State & $\begin{array}{l}\text { Videoconferenc- } \\
\text { ing, telephone }\end{array}$ & $\begin{array}{l}\text { Offering telemedicine } \\
\text { visits for patients }\end{array}$ \\
\hline Gilbert et al [34] & BMJ Open Quality & May & $\begin{array}{l}\text { United King- } \\
\text { dom }\end{array}$ & Prevention & City & $\begin{array}{l}\text { Videoconferenc- } \\
\text { ing, telephone }\end{array}$ & $\begin{array}{l}\text { Offering telemedicine } \\
\text { visits for patients }\end{array}$ \\
\hline Giudice et al [35] & $\begin{array}{l}\text { International Journal of En- } \\
\text { vironmental Research and } \\
\text { Public Health }\end{array}$ & May & Italy & Follow-up & Region & $\begin{array}{l}\text { Videoconferenc- } \\
\text { ing }\end{array}$ & $\begin{array}{l}\text { Offering telemedicine } \\
\text { visits for patients }\end{array}$ \\
\hline Gong et al [36] & $\begin{array}{l}\text { Journal of Medical Internet } \\
\text { Research }\end{array}$ & April & China & Prevention & Country & $\begin{array}{l}\text { Telecommunica- } \\
\text { tion system }\end{array}$ & $\begin{array}{l}\text { Offering telemedicine } \\
\text { visits for patients }\end{array}$ \\
\hline
\end{tabular}




\begin{tabular}{|c|c|c|c|c|c|c|c|}
\hline Author & Journal & $\begin{array}{l}\text { Publication } \\
\text { month } \\
(2020)\end{array}$ & Country & Purpose & $\begin{array}{l}\text { Scope and } \\
\text { territory }\end{array}$ & $\begin{array}{l}\text { Applied digital } \\
\text { tools }\end{array}$ & $\begin{array}{l}\text { Application of digital } \\
\text { tools }\end{array}$ \\
\hline Gong et al [37] & $\begin{array}{l}\text { Journal of Medical Internet } \\
\text { Research }\end{array}$ & April & China & Screening & City & $\begin{array}{l}\text { Cloud-based sys- } \\
\text { tem, mobile app, } \\
\text { CDSS }^{c}\end{array}$ & $\begin{array}{l}\text { Screening of cases } \\
\text { and detection of pa- } \\
\text { tients }\end{array}$ \\
\hline $\begin{array}{l}\text { Goodman- } \\
\text { Casanov et al } \\
{[38]}\end{array}$ & $\begin{array}{l}\text { Journal of Medical Internet } \\
\text { Research }\end{array}$ & April & Spain & Prevention & Country & $\begin{array}{l}\text { Telecommunica- } \\
\text { tion system }\end{array}$ & $\begin{array}{l}\text { Widespread distribu- } \\
\text { tion of information, } \\
\text { support for home care } \\
\text { and patient self-care }\end{array}$ \\
\hline Grange et al [39] & Applied Clinical Informatics & April & $\begin{array}{l}\text { United } \\
\text { States }\end{array}$ & $\begin{array}{l}\text { Prevention, } \\
\text { diagnosis, } \\
\text { treatment, } \\
\text { screening }\end{array}$ & State & $\begin{array}{l}\text { Videoconferenc- } \\
\text { ing, CDSS, } \\
\text { telecommunica- } \\
\text { tion }\end{array}$ & $\begin{array}{l}\text { Offering telemedicine } \\
\text { visits for patients }\end{array}$ \\
\hline Grenda et al [40] & Annals of Surgery & August & $\begin{array}{l}\text { United } \\
\text { States }\end{array}$ & $\begin{array}{l}\text { Diagnosis, } \\
\text { treatment }\end{array}$ & City & $\begin{array}{l}\text { Telecommunica- } \\
\text { tion, videoconfer- } \\
\text { encing }\end{array}$ & $\begin{array}{l}\text { Offering telemedicine } \\
\text { visits for patients }\end{array}$ \\
\hline $\begin{array}{l}\text { Grossman et al } \\
\text { [41] }\end{array}$ & Neurology & June & $\begin{array}{l}\text { United } \\
\text { States }\end{array}$ & $\begin{array}{l}\text { Diagnosis, } \\
\text { treatment }\end{array}$ & City & $\begin{array}{l}\text { Smartphone, mo- } \\
\text { bile apps }\end{array}$ & $\begin{array}{l}\text { Offering telemedicine } \\
\text { visits for patients }\end{array}$ \\
\hline Hames et al [42] & $\begin{array}{l}\text { Journal of Psychotherapy } \\
\text { Integration }\end{array}$ & April & $\begin{array}{l}\text { United } \\
\text { States, Cana- } \\
\text { da }\end{array}$ & Prevention & Country & $\begin{array}{l}\text { Telecommunica- } \\
\text { tion system }\end{array}$ & Training \\
\hline Hanna et al [43] & Modern Pathology & June & $\begin{array}{l}\text { United } \\
\text { States }\end{array}$ & $\begin{array}{l}\text { Prevention, } \\
\text { diagnosis }\end{array}$ & City & $\begin{array}{l}\text { Telecommunica- } \\
\text { tion system }\end{array}$ & Diagnosis \\
\hline Hom et al [44] & $\begin{array}{l}\text { Journal of Psychotherapy } \\
\text { Integration }\end{array}$ & April & $\begin{array}{l}\text { United } \\
\text { States }\end{array}$ & $\begin{array}{l}\text { Prevention, } \\
\text { treatment }\end{array}$ & City & $\begin{array}{l}\text { Videoconferenc- } \\
\text { ing }\end{array}$ & $\begin{array}{l}\text { Telemedicine visits } \\
\text { for patients, training }\end{array}$ \\
\hline Itamura et al [45] & OTO Open & April & $\begin{array}{l}\text { United } \\
\text { States }\end{array}$ & Prevention & Country & $\begin{array}{l}\text { Videoconferenc- } \\
\text { ing }\end{array}$ & $\begin{array}{l}\text { Telemedicine visits } \\
\text { for patients }\end{array}$ \\
\hline Judson et al [46] & $\begin{array}{l}\text { Journal of the American } \\
\text { Medical Informatics Associ- } \\
\text { ation }\end{array}$ & June & $\begin{array}{l}\text { United } \\
\text { States }\end{array}$ & Prevention & State & Website & $\begin{array}{l}\text { Screening of cases } \\
\text { and detection of pa- } \\
\text { tients }\end{array}$ \\
\hline Wu et al [47] & $\begin{array}{l}\text { European Respiratory Jour- } \\
\text { nal }\end{array}$ & June & $\begin{array}{l}\text { China, Italy, } \\
\text { Belgium }\end{array}$ & Diagnosis & $\begin{array}{l}\text { Internation- } \\
\text { al }\end{array}$ & CDSS & $\begin{array}{l}\text { Classification of pa- } \\
\text { tients in triage to find } \\
\text { the best route }\end{array}$ \\
\hline Wang et al [48] & JMIR mHealth and uHealth & June & China & Prevention & Country & $\begin{array}{l}\text { Mobile app } \\
\text { (WeChat) }\end{array}$ & $\begin{array}{l}\text { Early tracing and } \\
\text { quarantine of potential } \\
\text { sources of infection }\end{array}$ \\
\hline $\begin{array}{l}\text { Timmers et al } \\
\text { [49] }\end{array}$ & JMIR mHealth and uHealth & June & $\begin{array}{l}\text { The Nether- } \\
\text { lands }\end{array}$ & Prevention & Country & Mobile app & $\begin{array}{l}\text { Education, self-assess- } \\
\text { ment, and symptom } \\
\text { monitoring }\end{array}$ \\
\hline Pepin et al [50] & $\begin{array}{l}\text { Journal of Medical Internet } \\
\text { Research }\end{array}$ & June & France & Prevention & $\begin{array}{l}\text { Internation- } \\
\text { al }\end{array}$ & $\begin{array}{l}\text { Wearable devices } \\
\text { and activity } \\
\text { trackers }\end{array}$ & $\begin{array}{l}\text { Definition of the level } \\
\text { of quarantine }\end{array}$ \\
\hline Rabuna et al [51] & Telemedicine and e-Health & June & Spain & Prevention & Rural area & $\begin{array}{l}\text { TELEA digital } \\
\text { web platform }\end{array}$ & $\begin{array}{l}\text { Real-time tracking } \\
\text { and monitoring of pa- } \\
\text { tients; follow-up of } \\
\text { patients by telephone, } \\
\text { videoconferencing, } \\
\text { and email }\end{array}$ \\
\hline Cheng et al [52] & $\begin{array}{l}\text { Community Mental Health } \\
\text { Journal }\end{array}$ & July & $\begin{array}{l}\text { United } \\
\text { States, Cana- } \\
\text { da, Australia }\end{array}$ & Prevention & $\begin{array}{l}\text { Internation- } \\
\text { al }\end{array}$ & Mobile app & $\begin{array}{l}\text { Peer-to-peer psycho- } \\
\text { logical support for } \\
\text { Wuhan health care } \\
\text { professionals at the } \\
\text { front line of the crisis }\end{array}$ \\
\hline Castaldi et al [53] & Acta Biomedica & July & Italy & Prevention & Region & Social media & $\begin{array}{l}\text { Assessment of the dy- } \\
\text { namic burden of so- } \\
\text { cial anxiety through } \\
\text { analysis of data from } \\
\text { Facebook and Twitter }\end{array}$ \\
\hline
\end{tabular}




\begin{tabular}{|c|c|c|c|c|c|c|c|}
\hline Author & Journal & $\begin{array}{l}\text { Publication } \\
\text { month } \\
(2020)\end{array}$ & Country & Purpose & $\begin{array}{l}\text { Scope and } \\
\text { territory }\end{array}$ & $\begin{array}{l}\text { Applied digital } \\
\text { tools }\end{array}$ & $\begin{array}{l}\text { Application of digital } \\
\text { tools }\end{array}$ \\
\hline
\end{tabular}

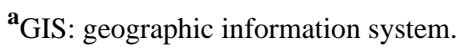

${ }^{\mathrm{b}} \mathrm{QR}$ : quick response.

${ }^{\mathrm{c}}$ CDSS: clinical decision support system.

\section{Results}

The search of scientific databases and manual searches retrieved 771 relevant articles. The titles and abstracts of all the retrieved publications were evaluated by two authors. Disagreements between the two evaluators were discussed and resolved by consensus. After removal of duplicates, 292 articles remained at this stage. Next, 260 publications were removed because they did not meet the inclusion criteria. Afterward, four authors independently reviewed the full text of the remaining publications $(\mathrm{N}=32)$. The reviewed papers were studied based on the variables shown in Table 1 and the different distributions discussed below.

For the purpose of this review, studies published from December 2019 to August 15, 2020, were reviewed. The survey identified 32 papers that demonstrated digital health applications to fight the COVID-19 pandemic. The distribution by publication month revealed that the publication of studies regarding digital health and COVID-19 began in February 2020, and the distribution of the 32 publications by month is February, $2(6 \%)$; March, 5 (16\%); April, 9 (28\%); May, 3 (9\%); June, 9 (28\%); July, 3 $(9 \%)$; and the first half of August, $1(3 \%)$.

The projects of digital health application for COVID-19 control were deployed at different geographical levels, from international to rural. Six countries carried out six international projects, and the most common collaborations were among European countries, the United States, China, and Australia. The digital health projects at the international level mainly aimed to track real-time transmission and infected cases, define the level of quarantine, and enable peer-to-peer consultation to support care providers in other countries phytologically and scientifically. The studies of digital health projects for a given purpose in the 32 studies were most frequently conducted at the country level $(n=10,31 \%)$, and the other geographical levels were state $(n=4,13 \%)$, region $(n=3,9 \%)$, city $(n=8,25 \%)$, and rural $(n=1,3 \%)$. The United States was the country with the highest number of studies of digital health projects to fight COVID-19 (12/32, 38\%), and these 12 studies varied the most in geographical scale, including international $(\mathrm{n}=3,25 \%)$, state $(n=3,25 \%)$, country $(n=2,17 \%)$, and city $(n=4,13 \%)$ levels. The other studied countries ranked by the number of conducted studies were China (11/32, 34\%); the United Kingdom (4/32, $13 \%)$; Canada, Spain, and Italy $(3 / 32,9 \%)$; Belgium and France $(2 / 32,6 \%)$; and the Netherlands $(1 / 32,3 \%)$.

To show the applied approaches of digital health for certain methods of COVID-19 control, the results were analyzed, and all the papers were categorized into six domains. These categories, their frequencies and percentages, and their applications for COVID-19 control are presented in Table 2. Some articles mentioned more than one approach to using digital health to control the COVID-19 pandemic.

Table 2. The frequency of digital health methods and their applications for COVID-19 pandemic control.

\begin{tabular}{llll}
\hline $\begin{array}{l}\text { Domain } \\
\text { number }\end{array}$ & Applied digital health solutions & COVID-19 control approaches & $\begin{array}{l}\text { Digital health application } \\
\text { projects }(\mathrm{N}=37), \mathrm{n}(\%)\end{array}$ \\
\hline 1 & $\begin{array}{l}\text { Digital learning package, mobile apps, and } \\
\text { web-based systems }\end{array}$ & Widespread distribution of information & $7(19)$ \\
2 & GISs $^{\mathrm{a}}, \mathrm{QR}^{\mathrm{b}}$ codes, and wearable devices & $\begin{array}{l}\text { Real-time tracking of transmission, activity tracking, and } \\
\text { quarantine-level analysis }\end{array}$ & $7(19)$ \\
3 & $\begin{array}{l}\text { Web-based systems and mobile apps, videocon- } \\
\text { ferencing, and telephone }\end{array}$ & Telemedicine visit services and virtual venues for meetings & $11(30)$ \\
4 & Cloud- and mobile-based systems & Self-care and patient monitoring, training, and diagnosis & $7(19)$ \\
5 & Intelligent systems and CDSSs & Early warning and detection, screening, and triage & $4(10)$ \\
6 & Social media & $\begin{array}{l}\text { Dynamic burden of the pandemic and analysis of its conse- } \\
\text { quences }\end{array}$ & $1(3)$ \\
\hline
\end{tabular}

${ }^{\mathrm{a}}$ GISs: geographic information systems.

${ }^{\mathrm{b}} \mathrm{QR}$ : quick response.

${ }^{\mathrm{c}}$ CDSSs: clinical decision support systems. 
According to the results, telemedicine visit services (11/37, $30 \%$ ), especially in the United States $(6 / 11,54 \%)$, were the most commonly applied pandemic control approach. Using electronic methods to inform people about the disease, methods to prevent disease spread, and protection methods was the second-ranked approach, in addition to two other solutions of geographic information systems (GISs), QR codes, and wearable devices for real-time transmission tracking as well as cloud-based and mobile app usage for patient monitoring and self-care at home (all 7/37, 19\%). A few studies were identified regarding the application of intelligent systems and CDSSs $(4 / 37,10 \%)$ and social media data analysis $(1 / 37,3 \%)$ for screening and burden of disease analysis purposes.

\section{Discussion}

\section{Principal Findings}

The COVID-19 pandemic has spread worldwide, costing lives and bringing upheaval and change to societies and economies. Although the global scientific community is racing to discover effective vaccines and therapeutics, the most essential defense remains public health measures such as personal hygiene and mass physical distancing. To successfully implement these two main measures, digital health and information technologies have emerged to support health systems, and they offer opportunities to reshape current health care systems. The aim of this study was to review the most significant digital health tools applied to fight COVID-19 in the 10 countries that have been most affected by the disease. These tools help governments and people to engage in strategies to control the COVID-19 pandemic through addressing the most urgent needs, including immediate outbreak response and impact mitigation. In China, which is the first country affected by the virus [55] and the most populous country globally, many researchers have worked on multiple aspects of SARS-CoV-2; it is the second most frequent origin country of the included studies. The burden of SARS-CoV-2 could be massive in populous countries; thus, these studies are worthy of investment in these countries. Studies that reported the development of models to predict epidemiological indicators were ignored, as they have not yet yielded any digital tools and require further development [56-59].

Distributing widespread information and tracking real-time transmission were the two most frequent goals of the studies. The former may originate from the importance of prevention in pandemic diseases as well as the simplest task of using information systems. The latter may be a focus in the literature because of the knowledge obtained from the previous experience of epidemics such as influenza and Zika virus [60-62]. Additionally, telemedicine visits for patients may be beneficial for populations because screening and follow-up of patients can be performed while maintaining social distancing in the population [63]. It appears that investigating the infrastructures needed for this technology could have great potential to mitigate these types of crises. In addition to the whole populations that can benefit from digital health technologies, more attention should be paid to interventions for travelers, as they can spread SARS-CoV-2 to other locations and even globally [64].
It has been shown that cell phones can be beneficial for health care [65]; due to their high influence among global populations, these tools are well suited for widespread distribution of information to these populations. Mobile apps are also used for tracking real-time transmission of SARS-CoV-2. Other potentially useful digital health tools are web-based apps and websites; these tools can also distribute information and track transmission. Videoconferencing and telecommunication also appear to be useful barriers to the spread of COVID-19 by enabling social distancing. Moreover, other industries may use teleservices to prevent the dissemination of disease.

Due to time limitations and the different times of onset of the epidemic in different countries, several digital health tools are not included in this paper. These tools have been reported in the news and other resources, and it may be valuable to discuss them as learned lessons for other countries fighting COVID-19. Therefore, we will review the digital health interventions in the different countries based on their available facilities and other requirements.

\section{China}

In China, multiple approaches are being used to manage the COVID-19 pandemic, ranging from web-based and mobile-based systems to cloud-based systems, CDSSs, and intelligent systems. The total number of cases of COVID-19 in this country showed a slight increase after March 1, 2020, based on the data in [66]. However, this decrease in COVID-19 cases was affected by multiple factors, and the effect of eHealth tools on the decrease should be evaluated. China has widely applied an eHealth app named Health Code to indicate a person's health status in the past day [67].

China has established a plan to spend approximately US \$1.4 trillion on digital infrastructure. This infrastructure upgrade program includes developing $5 \mathrm{G}$ networks, industrial internet, data centers, and artificial intelligence [68], which could improve the country's capability to fight pandemics.

\section{Italy and Spain}

In contrast to Spain, Italy ranks among the four least advanced European countries in the Digital Economy and Society Index published by the European Commission [69], and approximately half the population of Italy has insufficient digital literacy [70]. The adoption of technology to prevent and manage the COVID-19 pandemic is unremarkable in these two countries. However, a coronavirus-tracking app was developed in Spain [71]. The statistics of total COVID-19 cases showed a dramatic increase after March 1, 2020, in both countries [66]. It appears that these countries should invest more in technologies to manage the pandemic.

\section{United States}

The US government launched a portal [72] for the public that contains information on how to prevent and manage COVID-19. Moreover, the US Centers for Disease Control and Prevention website [73] contains more detailed medical information on the spreading mechanism, symptoms, prevention, and treatment of COVID-19. 


\section{France and Belgium}

The French app StopCovid was developed to trace infected people to control the spread of SARS-CoV-2. Privacy concerns arose regarding adoption of the app. Belgium has announced that a similar app adoption was canceled due to these issues [74].

\section{United Kingdom}

The NHS in the United Kingdom works on nine main areas to digitally respond to the pandemic: provide digital channels for citizen guidance and triage; enable remote and collaborative care with systems and data; deliver digital services for NHS Test and Trace; identify and protect vulnerable citizens; support planning with data, analysis, and dashboards; get data and insights to research communities; support clinical trials; provide secure infrastructure and support additional capacity; and plan for recovery, restarting services, and new needs. The government has categorized initiatives in these areas [75].

\section{Iran}

Although our study did not include any papers from this country, the Iranian Ministry of Health developed a national screening program website [76] to identify COVID-19 cases in the early stages.

\section{The Netherlands}

The Netherlands is one of the leading countries in Europe in digital health care and data. Approximately $90 \%$ of the population has digital records, and the Dutch government has invested over 400 million euros (US \$482,980,000) in digital health. Hospitals in the Netherlands have signed up for a COVID-19 web-based portal for sharing patient information. Video consultation was provided by more than 8000 health care providers [77].

\section{Germany}

The Health Innovation Hub, established by Germany's Ministry of Health, has published a list of trusted telemedicine applications. The services provided by these apps include remote consultation, risk assessment, and telemedicine services. Before 2018, the country did not allow remote consultations.

The German parliament passed the Digital Care Act, which acknowledged that digital health is crucial for fighting the COVID-19 pandemic [78].

Telemedicine systems are highly used in many countries. In European countries, tracking of patients was adopted due to its feasibility in smaller countries; also, home care and self-care receive a relatively large amount of focus in these countries. Intelligent systems, CDSSs, and intelligent triage systems are not well adopted due to the need to supply them with data. These data are being gathered worldwide. Furthermore, analysis of social health data could be interesting, although little research has been done in this regard. Figure 1 shows the extent of the technologies developed for fighting the COVID-19 pandemic in the literature.

Figure 1. Technologies currently being applied to address the COVID-19 pandemic. QR: quick response.

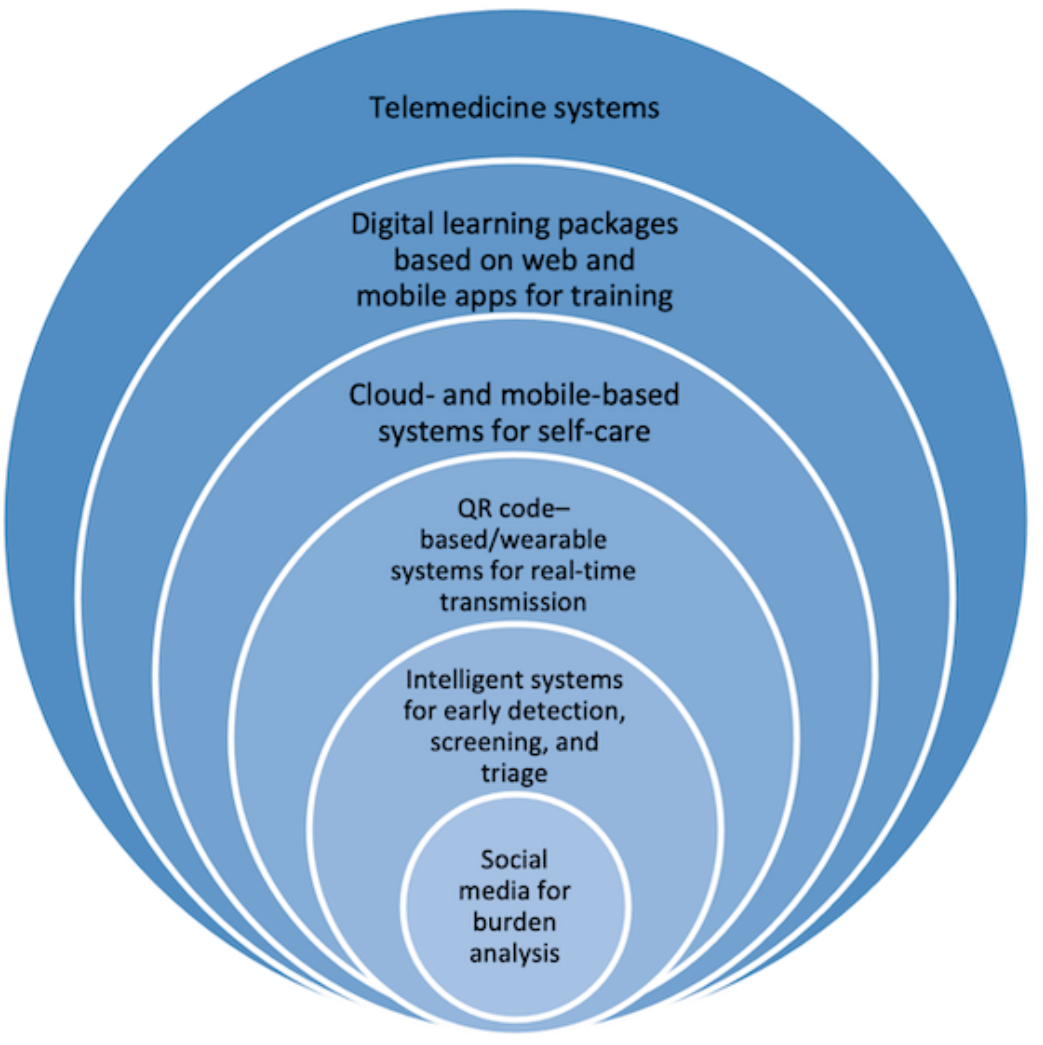

Overall, in the studied countries, after the alarm was raised regarding the pandemic, implementation of eHealth strategies began immediately. mHealth solutions and large-scale deployment of virtual consultations were launched. Data analysis approaches are being applied to support decision makers, and websites and electronic training tools are being used to improve patients' protective behaviors. Although this study presents digital tools that are being applied for pandemic control in 
general, it lacks evaluation of the exact outcomes of using these digital health tools; thus, further studies are needed to evaluate the effects and outcomes of using digital health tools. This study could help health policy makers make decisions regarding the investment of these tools to control COVID-19.

\section{Conclusion}

This study reviewed the digital health tools to fight COVID-19 that have been reported in the 10 countries in which the disease is most prevalent. Although there is no equal strategy to apply digital health tools across the affected countries for pandemic control, these tools are among the primary policies that governmental and private companies have considered for disease control. The United States has developed the most technologies to fight the pandemic. Furthermore, China, the first country that was affected by COVID-19, has applied a great number of digital tools, such as epidemiological indicators, analysis platforms, drones, robots, mobile apps, training websites and educational media, videoconferencing, smart infection detectors, intelligent patient tracers, and telemedicine systems. Having considered the potential of available information technologies worldwide in the 21 st century, particularly in developed countries, it appears that more digital health products, especially intelligent products, remain to be created and applied for the management of viral infections and other health crises.

\section{Conflicts of Interest}

None declared.

\section{References}

1. Zhu N, Zhang D, Wang W, Li X, Yang B, Song J, et al. A Novel Coronavirus from Patients with Pneumonia in China, 2019. N Engl J Med 2020 Feb 20;382(8):727-733. [doi: 10.1056/nejmoa2001017]

2. Responding to community spread of COVID-19: interim guidance. World Health Organization. URL: https://apps.who.int/ iris/bitstream/handle/10665/331421/WHO-COVID-19-Community_Transmission-2020.1-eng.pdf?sequence=1\&isAllowed=y [accessed 2021-03-04]

3. Guan W, Ni Z, Hu Y, Liang W, Ou C, He J, et al. Clinical characteristics of coronavirus disease 2019 in China. N Engl J Med 2020 Apr 30;382(18):1708-1720. [doi: 10.1056/nejmoa2002032]

4. Atreja A, Gordon SM, Pollock DA, Olmsted RN, Brennan PJ, Healthcare Infection Control Practices Advisory Committee. Opportunities and challenges in utilizing electronic health records for infection surveillance, prevention, and control. Am J Infect Control 2008 Apr;36(3 Suppl):S37-S46 [FREE Full text] [doi: 10.1016/j.ajic.2008.01.002] [Medline: 18374211]

5. NHS Digital. URL: https://digital.nhs.uk/ [accessed 2021-03-06]

6. Bhavnani SP, Narula J, Sengupta PP. Mobile technology and the digitization of healthcare. Eur Heart J 2016 May 07;37(18):1428-1438 [FREE Full text] [doi: 10.1093/eurheartj/ehv770] [Medline: 26873093]

7. Joshi AU, Randolph FT, Chang AM, Slovis BH, Rising KL, Sabonjian M, et al. Impact of emergency department tele-intake on left without being seen and throughput metrics. Acad Emerg Med 2020 Feb 26;27(2):139-147 [FREE Full text] [doi: 10.1111/acem.13890] [Medline: 31733003]

8. Langabeer J, Gonzalez M, Alqusairi D, Champagne-Langabeer T, Jackson A, Mikhail J, et al. Telehealth-enabled emergency medical services program reduces ambulance transport to urban emergency departments. West J Emerg Med 2016 Nov;17(6):713-720 [FREE Full text] [doi: 10.5811/westjem.2016.8.30660] [Medline: 27833678]

9. Hollander JE, Carr BG. Virtually perfect? Telemedicine for Covid-19. N Engl J Med 2020 Apr 30;382(18):1679-1681. [doi: 10.1056/nejmp2003539]

10. Lurie N, Carr BG. The role of telehealth in the medical response to disasters. JAMA Intern Med 2018 Jun 01;178(6):745-746. [doi: 10.1001/jamainternmed.2018.1314] [Medline: 29710200]

11. Dong E, Du H, Gardner L. An interactive web-based dashboard to track COVID-19 in real time. Lancet Infect Dis 2020 May;20(5):533-534. [doi: 10.1016/s1473-3099(20)30120-1]

12. Reeves J, Hollandsworth H, Torriani F, Taplitz R, Abeles S, Tai-Seale M, et al. Rapid response to COVID-19: health informatics support for outbreak management in an academic health system. J Am Med Inform Assoc 2020 Jun 01;27(6):853-859 [FREE Full text] [doi: 10.1093/jamia/ocaa037] [Medline: 32208481]

13. Scott BK, Miller GT, Fonda SJ, Yeaw RE, Gaudaen JC, Pavliscsak HH, et al. Advanced digital health technologies for COVID-19 and future emergencies. Telemed J E Health 2020 Oct 01;26(10):1226-1233. [doi: 10.1089/tmj.2020.0140] [Medline: 32456560]

14. Bayram M, Springer S, Garvey CK, Özdemir V. COVID-19 digital health innovation policy: a portal to alternative futures in the making. OMICS 2020 Aug 01;24(8):460-469. [doi: 10.1089/omi.2020.0089] [Medline: 32511054]

15. Torous J, Jän Myrick K, Rauseo-Ricupero N, Firth J. Digital mental health and COVID-19: using technology today to accelerate the curve on access and quality tomorrow. JMIR Ment Health 2020 Mar 26;7(3):e18848 [FREE Full text] [doi: 10.2196/18848] [Medline: $\underline{32213476]}$

16. Calton B, Abedini N, Fratkin M. Telemedicine in the time of coronavirus. J Pain Symptom Manage 2020 Jul;60(1):e12-e14 [FREE Full text] [doi: 10.1016/j.jpainsymman.2020.03.019] [Medline: 32240756] 
17. Moazzami B, Razavi-Khorasani N, Dooghaie Moghadam A, Farokhi E, Rezaei N. COVID-19 and telemedicine: Immediate action required for maintaining healthcare providers well-being. J Clin Virol 2020 May;126:104345 [FREE Full text] [doi: 10.1016/j.jcv.2020.104345] [Medline: 32278298]

18. Keesara S, Jonas A, Schulman K. Covid-19 and health care's digital revolution. N Engl J Med 2020 Jun 04;382(23):e82. [doi: 10.1056/NEJMp2005835] [Medline: 32240581]

19. Alwashmi MF. The use of digital health in the detection and management of COVID-19. Int J Environ Res Public Health 2020 Apr 23;17(8):2906 [FREE Full text] [doi: 10.3390/ijerph17082906] [Medline: 32340107]

20. Fagherazzi G, Goetzinger C, Rashid M, Aguayo G, Huiart L. Digital health strategies to fight COVID-19 worldwide: challenges, recommendations, and a call for papers. J Med Internet Res 2020 Jun 16;22(6):e19284 [FREE Full text] [doi: 10.2196/19284] [Medline: 32501804]

21. Sarbadhikari S, Sarbadhikari S. The global experience of digital health interventions in COVID-19 management. Indian J Public Health 2020;64(6):117. [doi: 10.4103/ijph.ijph $457 \quad 20$ ]

22. COVID-19 coronavirus pandemic. Worldometer. URL: https://www.worldometers.info/coronavirus/ [accessed 2021-03-04]

23. Kamel Boulos MN, Geraghty EM. Geographical tracking and mapping of coronavirus disease COVID-19/severe acute respiratory syndrome coronavirus 2 (SARS-CoV-2) epidemic and associated events around the world: how 21st century GIS technologies are supporting the global fight against outbreaks and epidemics. Int J Health Geogr 2020 Mar 11;19(1):8 [FREE Full text] [doi: 10.1186/s12942-020-00202-8] [Medline: 32160889]

24. Yang Y, Zhou Y, Liu X, Tan J. Health services provision of 48 public tertiary dental hospitals during the COVID-19 epidemic in China. Clin Oral Investig 2020 May;24(5):1861-1864 [FREE Full text] [doi: 10.1007/s00784-020-03267-8] [Medline: 32246280]

25. Meng L, Qiu F, Sun S. Providing pharmacy services at cabin hospitals at the coronavirus epicenter in China. Int J Clin Pharm 2020 Apr 2;42(2):305-308 [FREE Full text] [doi: 10.1007/s11096-020-01020-5] [Medline: 32240484]

26. Ohannessian R, Duong TA, Odone A. Global telemedicine implementation and integration within health systems to fight the COVID-19 Pandemic: a call to action. JMIR Public Health Surveill 2020 Apr 02;6(2):e18810 [FREE Full text] [doi: 10.2196/18810] [Medline: 32238336$]$

27. Pan X, Ojcius DM, Gao T, Li Z, Pan C, Pan C. Lessons learned from the 2019-nCoV epidemic on prevention of future infectious diseases. Microbes Infect 2020 Mar 27;22(2):86-91 [FREE Full text] [doi: 10.1016/j.micinf.2020.02.004] [Medline: 32088333]

28. Pan X. Application of personal-oriented digital technology in preventing transmission of COVID-19, China. Ir J Med Sci 2020 Nov 27;189(4):1145-1146 [FREE Full text] [doi: 10.1007/s11845-020-02215-5] [Medline: $\underline{\text { 32219674] }}$

29. Sun Q, Qiu H, Huang M, Yang Y. Lower mortality of COVID-19 by early recognition and intervention: experience from Jiangsu Province. Ann Intensive Care 2020 Mar 18;10(1):33 [FREE Full text] [doi: 10.1186/s13613-020-00650-2] [Medline: 32189136]

30. Hernández-García I, Giménez-Júlvez T. Assessment of health information about COVID-19 prevention on the internet: infodemiological study. JMIR Public Health Surveill 2020 Apr 01;6(2):e18717 [FREE Full text] [doi: 10.2196/18717] [Medline: $\underline{32217507]}$

31. Hua J, Shaw R. Corona virus (COVID-19) "infodemic" and emerging issues through a data lens: the case of China. Int J Environ Res Public Health 2020 Mar 30;17(7):2309 [FREE Full text] [doi: 10.3390/ijerph17072309] [Medline: 32235433]

32. Drew DA, Nguyen LH, Steves CJ, Menni C, Freydin M, Varsavsky T, COPE Consortium. Rapid implementation of mobile technology for real-time epidemiology of COVID-19. Science 2020 Jun 19;368(6497):1362-1367 [FREE Full text] [doi: 10.1126/science.abc0473] [Medline: 32371477]

33. Franco D, Montenegro T, Gonzalez GA, Hines K, Mahtabfar A, Helgeson MD, et al. Telemedicine for the spine surgeon in the age of COVID-19: multicenter experiences of feasibility and implementation strategies. Global Spine J 2020 Jun 03:2192568220932168 [FREE Full text] [doi: 10.1177/2192568220932168] [Medline: $\underline{32677513}$ ]

34. Gilbert AW, Billany JCT, Adam R, Martin L, Tobin R, Bagdai S, et al. Rapid implementation of virtual clinics due to COVID-19: report and early evaluation of a quality improvement initiative. BMJ Open Qual 2020 May 21;9(2):e000985 [FREE Full text] [doi: 10.1136/bmjoq-2020-000985] [Medline: $\underline{\text { 32439740] }}$

35. Giudice A, Barone S, Muraca D, Averta F, Diodati F, Antonelli A, et al. Can teledentistry improve the monitoring of patients during the Covid-19 dissemination? A descriptive pilot study. Int J Environ Res Public Health 2020 May 13;17(10):3399 [FREE Full text] [doi: 10.3390/ijerph17103399] [Medline: $\underline{\text { 32414126] }}$

36. Gong K, Xu Z, Cai Z, Chen Y, Wang Z. Internet hospitals help prevent and control the epidemic of COVID-19 in China: multicenter user profiling Study. J Med Internet Res 2020 Apr 14;22(4):e18908 [FREE Full text] [doi: 10.2196/18908] [Medline: 32250962]

37. Gong M, Liu L, Sun X, Yang Y, Wang S, Zhu H. Cloud-based system for effective surveillance and control of COVID-19: useful experiences from Hubei, China. J Med Internet Res 2020 Apr 22;22(4):e18948 [FREE Full text] [doi: 10.2196/18948] [Medline: $\underline{32287040}$ ]

38. Goodman-Casanova JM, Dura-Perez E, Guzman-Parra J, Cuesta-Vargas A, Mayoral-Cleries F. Telehealth home support during COVID-19 confinement for community-dwelling older adults with mild cognitive impairment or mild dementia: survey study. J Med Internet Res 2020 May 22;22(5):e19434 [FREE Full text] [doi: 10.2196/19434] [Medline: 32401215] 
39. Grange ES, Neil EJ, Stoffel M, Singh AP, Tseng E, Resco-Summers K, et al. Responding to COVID-19: The UW Medicine Information Technology Services Experience. Appl Clin Inform 2020 Mar 08;11(2):265-275 [FREE Full text] [doi: 10.1055/s-0040-1709715] [Medline: $\underline{32268390}$ ]

40. Grenda T, Whang S, Evans N. Transitioning a surgery practice to telehealth during COVID-19. Ann Surg 2020 Aug;272(2):e168-e169 [FREE Full text] [doi: 10.1097/SLA.0000000000004008] [Medline: $\underline{\text { 32675529] }}$

41. Grossman SN, Han SC, Balcer LJ, Kurzweil A, Weinberg H, Galetta SL, et al. Rapid implementation of virtual neurology in response to the COVID-19 pandemic. Neurology 2020 Jun 16;94(24):1077-1087. [doi: 10.1212/WNL.0000000000009677] [Medline: 32358217]

42. Hames JL, Bell DJ, Perez-Lima LM, Holm-Denoma JM, Rooney T, Charles NE, et al. Navigating uncharted waters: considerations for training clinics in the rapid transition to telepsychology and telesupervision during COVID-19. J Psychother Integr 2020 Jun;30(2):348-365. [doi: 10.1037/int0000224]

43. Hanna MG, Reuter VE, Ardon O, Kim D, Sirintrapun SJ, Schüffler PJ, et al. Validation of a digital pathology system including remote review during the COVID-19 pandemic. Mod Pathol 2020 Nov 22;33(11):2115-2127 [FREE Full text] [doi: 10.1038/s41379-020-0601-5] [Medline: 32572154]

44. Hom MA, Weiss RB, Millman ZB, Christensen K, Lewis EJ, Cho S, et al. Development of a virtual partial hospital program for an acute psychiatric population: Lessons learned and future directions for telepsychotherapy. J Psychother Integr 2020 Jun;30(2):366-382. [doi: 10.1037/int0000212]

45. Itamura K, Rimell FL, Illing EA, Higgins TS, Ting JY, Lee MK, et al. Assessment of patient experiences in otolaryngology virtual visits during the COVID-19 pandemic. OTO Open 2020 Jun 08;4(2):2473974X2093357. [doi: $10.1177 / 2473974 \times 20933573]$

46. Judson T, Odisho A, Neinstein A, Chao J, Williams A, Miller C, et al. Rapid design and implementation of an integrated patient self-triage and self-scheduling tool for COVID-19. J Am Med Inform Assoc 2020 Jun 01;27(6):860-866 [FREE Full text] [doi: 10.1093/jamia/ocaa051] [Medline: $\underline{\text { 32267928] }}$

47. Wu G, Yang P, Xie Y, Woodruff HC, Rao X, Guiot J, et al. Development of a clinical decision support system for severity risk prediction and triage of COVID-19 patients at hospital admission: an international multicentre study. Eur Respir J 2020 Aug 02;56(2):2001104 [FREE Full text] [doi: 10.1183/13993003.01104-2020] [Medline: 32616597]

48. Wang S, Ding S, Xiong L. A new system for surveillance and digital contact tracing for COVID-19: spatiotemporal reporting over network and GPS. JMIR mHealth uHealth 2020 Jun 10;8(6):e19457 [FREE Full text] [doi: 10.2196/19457] [Medline: 32499212]

49. Timmers T, Janssen L, Stohr J, Murk J, Berrevoets MAH. Using eHealth to support COVID-19 education, self-assessment, and symptom monitoring in the Netherlands: observational study. JMIR mHealth uHealth 2020 Jun 23;8(6):e19822 [FREE Full text] [doi: 10.2196/19822] [Medline: $\underline{\text { 32516750] }}$

50. Pépin JL, Bruno RM, Yang R, Vercamer V, Jouhaud P, Escourrou P, et al. Wearable activity trackers for monitoring adherence to home confinement during the COVID-19 pandemic worldwide: data aggregation and analysis. J Med Internet Res 2020 Jun 19;22(6):e19787 [FREE Full text] [doi: 10.2196/19787] [Medline: 32501803 ]

51. Rabuñal R, Suarez-Gil R, Golpe R, Martínez-García M, Gómez-Méndez R, Romay-Lema E, et al. Usefulness of a telemedicine tool TELEA in the management of the COVID-19 pandemic. Telemed J E Health 2020 Nov 01;26(11):1332-1335. [doi: 10.1089/tmj.2020.0144] [Medline: 32501747]

52. Cheng P, Xia G, Pang P, Wu B, Jiang W, Li Y, et al. COVID-19 epidemic peer support and crisis intervention via social media. Community Ment Health J 2020 Jul 6;56(5):786-792 [FREE Full text] [doi: 10.1007/s10597-020-00624-5] [Medline: $\underline{32378126]}$

53. Castaldi S, Maffeo M, Rivieccio B, Zignani M, Manzi G, Nicolussi F, et al. Monitoring emergency calls and social networks for COVID-19 surveillance. To learn for the future: the outbreak experience of the Lombardia region in Italy. Acta Biomed 2020 Jul 20;91(9-S):29-33. [doi: 10.23750/abm.v91i9-S.10038] [Medline: 32701914]

54. Blake H, Bermingham F, Johnson G, Tabner A. Mitigating the psychological impact of COVID-19 on healthcare workers: a digital learning package. Int J Environ Res Public Health 2020 Apr 26;17(9):2997 [FREE Full text] [doi: 10.3390/ijerph17092997] [Medline: 32357424]

55. Guo Y, Cao Q, Hong Z, Tan Y, Chen S, Jin H, et al. The origin, transmission and clinical therapies on coronavirus disease 2019 (COVID-19) outbreak - an update on the status. Mil Med Res 2020 Mar 13;7(1):11 [FREE Full text] [doi: 10.1186/s40779-020-00240-0] [Medline: 32169119]

56. Ayyoubzadeh S, Ayyoubzadeh S, Zahedi H, Ahmadi M, R Niakan Kalhori S. Predicting COVID-19 incidence through analysis of Google Trends data in Iran: data mining and deep learning pilot study. JMIR Public Health Surveill 2020 Apr 14;6(2):e18828 [FREE Full text] [doi: 10.2196/18828] [Medline: 32234709]

57. Qiang X, Xu P, Fang G, Liu W, Kou Z. Using the spike protein feature to predict infection risk and monitor the evolutionary dynamic of coronavirus. Infect Dis Poverty 2020 Mar 25;9(1):33 [FREE Full text] [doi: 10.1186/s40249-020-00649-8] [Medline: 32209118]

58. Verity R, Okell LC, Dorigatti I, Winskill P, Whittaker C, Imai N, et al. Estimates of the severity of coronavirus disease 2019: a model-based analysis. Lancet Infect Dis 2020 Jun;20(6):669-677. [doi: 10.1016/s1473-3099(20)30243-7] 
59. Wu J, Leung K, Leung G. Nowcasting and forecasting the potential domestic and international spread of the 2019-nCoV outbreak originating in Wuhan, China: a modelling study. Lancet 2020 Feb;395(10225):689-697. [doi: 10.1016/s0140-6736(20)30260-9]

60. Santillana M, Nguyen AT, Dredze M, Paul MJ, Nsoesie EO, Brownstein JS. Combining search, social media, and traditional data sources to improve influenza surveillance. PLoS Comput Biol 2015 Oct 29;11(10):e1004513 [FREE Full text] [doi: 10.1371/journal.pcbi.1004513] [Medline: 26513245]

61. McGough SF, Brownstein JS, Hawkins JB, Santillana M. Forecasting Zika incidence in the 2016 Latin America outbreak combining traditional disease surveillance with search, social media, and news report data. PLoS Negl Trop Dis 2017 Jan 13;11(1):e0005295. [doi: 10.1371/journal.pntd.0005295] [Medline: 28085877]

62. Majumder MS, Santillana M, Mekaru SR, McGinnis DP, Khan K, Brownstein JS. Utilizing nontraditional data sources for near real-time estimation of transmission dynamics during the 2015-2016 Colombian Zika virus disease outbreak. JMIR Public Health Surveill 2016 Jun 01;2(1):e30 [FREE Full text] [doi: 10.2196/publichealth.5814] [Medline: 27251981]

63. Serper M, Cubell AW, Deleener ME, Casher TK, Rosenberg DJ, Whitebloom D, et al. Telemedicine in liver disease and beyond: can the COVID-19 crisis lead to action? Hepatology 2020 Aug 25;72(2):723-728 [FREE Full text] [doi: 10.1002/hep.31276] [Medline: 32275784]

64. Wilson ME. What goes on board aircraft? Passengers include Aedes, Anopheles, 2019-nCoV, dengue, Salmonella, Zika, et al. Travel Med Infect Dis 2020;33:101572 [FREE Full text] [doi: 10.1016/j.tmaid.2020.101572] [Medline: 32035269]

65. Krishna S, Boren SA, Balas EA. Healthcare via cell phones: a systematic review. Telemed J E Health 2009 Apr;15(3):231-240. [doi: 10.1089/tmj.2008.0099] [Medline: 19382860]

66. Jibb LA, Cafazzo JA, Nathan PC, Seto E, Stevens BJ, Nguyen C, et al. Development of a mHealth real-time pain self-management app for adolescents with cancer: an iterative usability testing study. J Pediatr Oncol Nurs 2017 Apr 04;34(4):283-294. [doi: 10.1177/1043454217697022] [Medline: 28376666]

67. Kim H, Lee H, Park JI, Choi CH, Park S, Kim HJ, et al. Smartphone application for mechanical quality assurance of medical linear accelerators. Phys Med Biol 2017 Jun 07;62(11):N257-N270. [doi: 10.1088/1361-6560/aa67d5] [Medline: 28319042]

68. Wong D. How Can Foreign Technology Investors Benefit from China's New Infrastructure Plan? China Briefing. 2020 Aug 07. URL: https://www.china-briefing.com/news/ how-foreign-technology-investors-benefit-from-chinas-new-infrastructure-plan/ [accessed 2021-03-04]

69. The Digital Economy and Society Index (DESI). European Commission. URL: https://ec.europa.eu/digital-single-market/ en/digital-economy-and-society-index-desi [accessed 2021-03-08]

70. Guerrini F. How the coronavirus is forcing Italy to become a digital country, at last. Forbes. 2020 Mar 14. URL: https:/ /www.forbes.com/sites/federicoguerrini/2020/03/14/how-the-coronavirus-is-forcing-italy-to-become-a-digital-country-at-last/ ?sh=649ae9376f75 [accessed 2021-03-04]

71. Vega G. Spain launches first phase of coronavirus-tracking app. El País. 2020 Jun 29. URL: https://english.elpais.com/ society/2020-06-29/spain-launches-first-phase-of-coronavirus-tracking-app.html [accessed 2021-03-04]

72. Coronavirus (COVID-19). US Centers for Disease Control and Prevention and Federal Emergency Management Agency. URL: https://www.coronavirus.gov/ [accessed 2021-03-06]

73. COVID-19.: Centers for Disease Control and Prevention URL: https://www.cdc.gov/coronavirus/2019-ncov/index.html [accessed 2021-03-06]

74. Thompson R. StopCOVID: France's controversial tracing app ready by June. Euronews. 2020 May 05. URL: https://www. euronews.com/2020/04/29/coronavirus-french-mps-approve-covid-19-tracing-app-despite-privacy-concerns [accessed 2021-03-04]

75. NHS Digital COVID-19 Update. NHS Digital. 2020 Apr 30. URL: https://digital.nhs.uk/binaries/content/assets/website-assets/ coronavirus/nhs-digital-covid-19-update-april-2020.pdf [accessed 2021-03-06]

76. New corona screening and care (COVID-19). Iran Ministry of Health and Medical Education. URL: https://salamat.gov.ir/ [accessed 2021-03-06]

77. How the Dutch are responding to coronavirus with digital healthcare. Invest in Holland. 2020 May 01. URL: https:/ /investinholland.com/news/how-dutch-have-responded-digitally-corona-crisis/ \#: :text=Pharos\%20responded\%20to\%20this\%20challenge,joint\%2Dcooperation $\% 20$ with\%20other\%20parties. \&text $=$ In $\% 20$ the $\% 20$ Netherlands $\% 2 C \% 20$ the $\% 20$ Dutch,step $\% 20$ up $\% 20$ innovative $\% 20$ eHealth $\% 20$ solutions [accessed 2021-03-04]

78. How Germany leveraged digital health to combat COVID-19. The Medical Futurist. 2020 Apr 09. URL: https:/ /medicalfuturist.com/how-germany-leveraged-digital-health-to-combat-covid-19/ [accessed 2021-03-04]

\section{Abbreviations}

CDSS: clinical decision support system

GIS: geographic information system

mHealth: mobile health

NHS: National Health Service 
QR: quick response

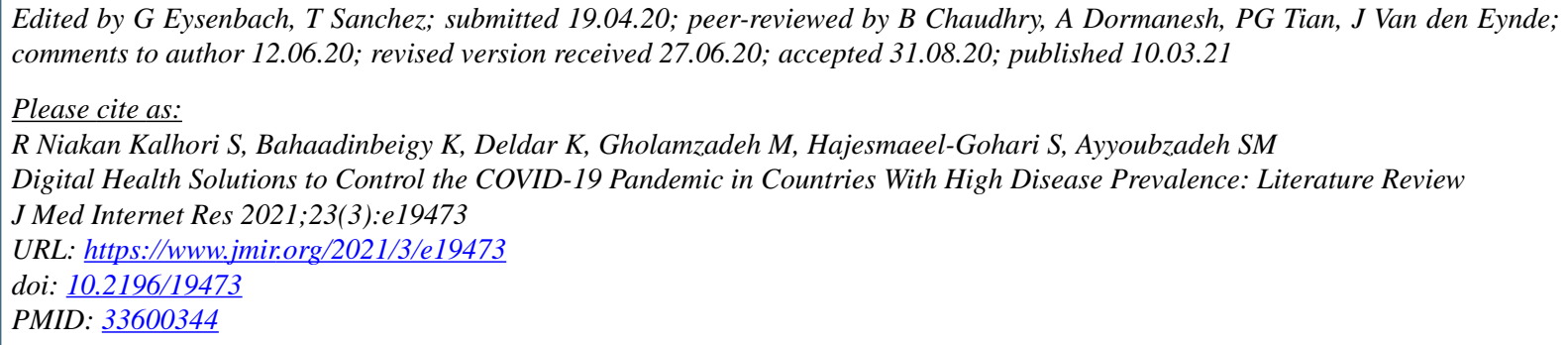

(C) Sharareh R Niakan Kalhori, Kambiz Bahaadinbeigy, Kolsoum Deldar, Marsa Gholamzadeh, Sadrieh Hajesmaeel-Gohari, Seyed Mohammad Ayyoubzadeh. Originally published in the Journal of Medical Internet Research (http://www.jmir.org), 10.03.2021. This is an open-access article distributed under the terms of the Creative Commons Attribution License (https://creativecommons.org/licenses/by/4.0/), which permits unrestricted use, distribution, and reproduction in any medium, provided the original work, first published in the Journal of Medical Internet Research, is properly cited. The complete bibliographic information, a link to the original publication on http://www.jmir.org/, as well as this copyright and license information must be included. 